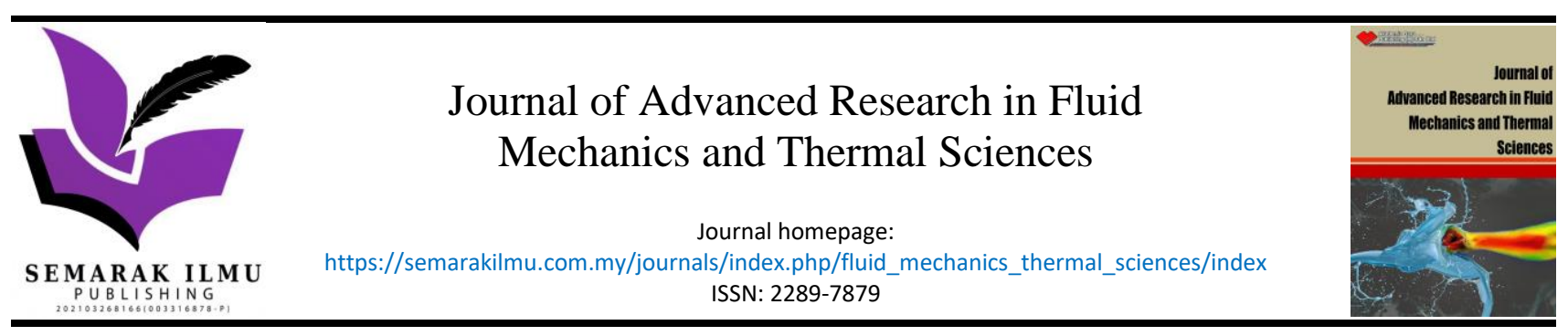

\title{
Thermal Imaging Study on The Effect of Permeability on Smouldering Behaviour of a Tropical Peat
}

\author{
Irfan Pratantyo ${ }^{1}$, Gatot Prayogo ${ }^{1}$, Agus Sunjarianto Pamitran ${ }^{1}$, Yulianto Sulistyo Nugroho ${ }^{1, *}$ \\ Department of Mechanical Engineering, Faculty of Engineering, Universitas Indonesia, Depok, Indonesia
}

\section{ARTICLE INFO ABSTRACT}

\section{Article history:}

Received 29 July 2021

Received in revised form 15 October 2021

Accepted 19 October 2021

Available online 25 November 2021

Keywords:

Peat Soil; Smouldering; Compaction

\begin{abstract}
Smouldering is a slow-burning, low-temperature, flameless combustion, and frequently happens in peatland fires. The smouldering spread occurs because of the parameter achievement in oxygen supply, generated heat, and heat released to the environment. The condition of porous and fibrous peat soils makes oxygen supply easily happens. The difficulty of getting to the location of the burning peatland is one of the problems to extinguish the fire. This study aims to observe with thermal imaging study the effect of peat permeability on smouldering behaviour of a tropical peat sample. Mechanical compaction was applied to reduce permeability and pore value in the central of the peat soil. Then, peat soil is ignited to create the smouldering propagation through the compacted peat area. The combustion process that occurs on the surface is observed by a visual camera and an Infrared FLIR Thermal Camera. The initial results showed a reduction in the smouldering spread rate on the compacted soil region as compared to the undisturbed peat smouldering region. Nevertheless, smouldering combustion of peat still occurred in all regions of the reactor, once the smouldering front could penetrate the compacted region.
\end{abstract}

\section{Introduction}

Peat is a mixture of segmented organic matter formed in wetlands on climatic conditions and suitable topography. Peat is formed from vegetation with chemical changes over many years [1] that known to have a high level of compressibility and low shear stress [2]. Because of its tropical climate, Indonesia has abundant peatlands measuring at 22.5 million hectares of peatlands [3]. However, due to organic compounds in peat, this soil is flammable and damaged by illegal logging [4]. The problem of forest and land fires in Indonesia is not something new for the government $[5,6]$. The forest and land fires, including peat fires, have caused significant economic loss and health problems [7]. Peat fires are related to the opening of agricultural land so that peat becomes very dry and burning. This fire phenomenon is caused by smoldering combustion, where the burning is moving slowly, lowtemperature, does not form a flame, supported by heat from oxygen that burns fuel $[8,9]$, and drying kinetic properties of the peat [10]. Because of that, the results of burning smoldering against peat

\footnotetext{
* Corresponding author.

E-mail address: yulianto.nugroho@ui.ac.id
}

https://doi.org/10.37934/arfmts.89.1.154159 
are very poisonous and often not detected, making it difficult to overcome the fire. There are three ways to extinguish peatland fires; cooling, eliminate oxygen and extinguishes fire sources [11]. With this in mind, the authors would like to visually study the effects of peat permeability on smoldering propagation by compaction using a peat sample originated from the Palangka Raya region in Central Kalimantan. Compaction is an attempt to rearrange the composition of the soil grains so that the soil becomes denser [12]. Density is usually the standard parameter of construction work because there is a direct correlation between the desired property and the soil density [13]. Compaction densifies air, water and earth so that the air is pushed and becomes less, resulting in permeability reduction and oxygen elimination. Compaction also increasing bulk density, where it constrained the oxygen diffusion through the peat particles, cause a decrease in mass loss rate and spread rate of smoldering peat $[14,15]$. This experiment aims as a preliminary study before a more detailed study involving local temperatures measurements, spread rate and emission studies.

\section{Methodology}

\subsection{Experimental Set-Up}

Figure 1 shows the experimental set-up and initial steps to start the experiment. Firstly, the undisturbed peat sample from Palangka Raya, Central Kalimantan, was oven-dried at $100^{\circ} \mathrm{C}$ to $11 \%$ moisture content. Then, the peat was poured without compaction into a $20 \times 20 \mathrm{~cm}$ stainless steel reactor. A fraction of the peat bed located at the center section of the reactor was then compacted with a special compactor to study the effect of permeability on smoldering behavior. The smoldering experiment was initiated by turning on a voltage regulator connected to the coil heater installed on one side of the reactor. The electric coil heater provides ignition energy of 100 Watts for 1 hour or until the smoldering propagation is self-sustained. An Infrared FLIR camera and a visual camera were placed above the reactor to visually observe the distribution of surface temperatures and the propagation dynamics of the smoldering peat. These cameras were connected directly to a laptop which recorded the data at intervals of 1 minute. At the later stage, the collected data were processed and analyzed. At the current experimental work, the temperature measurement was logged using a thermal camera. No thermocouples (TCS) were inserted into the peat layer because the compaction can potentially damage the TCs.

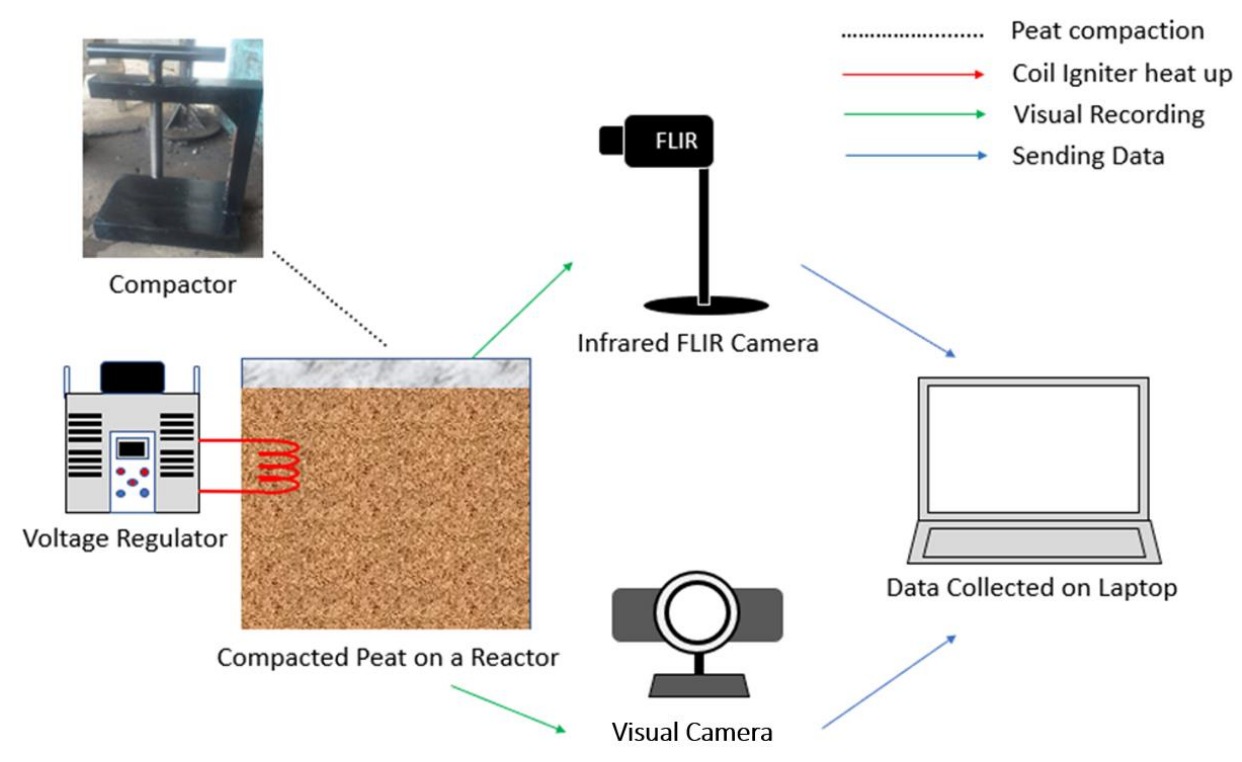

Fig. 1. Experimental Set-Up 


\subsection{Peat Compaction Area}

In order to create a layer of peat bed with a denser section, the peat was compacted using a manual compactor made of a stainless plate of $5 \mathrm{~cm}$ width (Figure 2). The compaction process was carried out three times with a holding time of 30 minutes per compaction. In order to protect the density of the side section, barrier plates were placed during the compaction process. At the end of each compaction stage, the empty part at the top was refilled with peat until the compacted section has the same height as the reactor tip. The barrier plates were removed before the ignition protocol started.
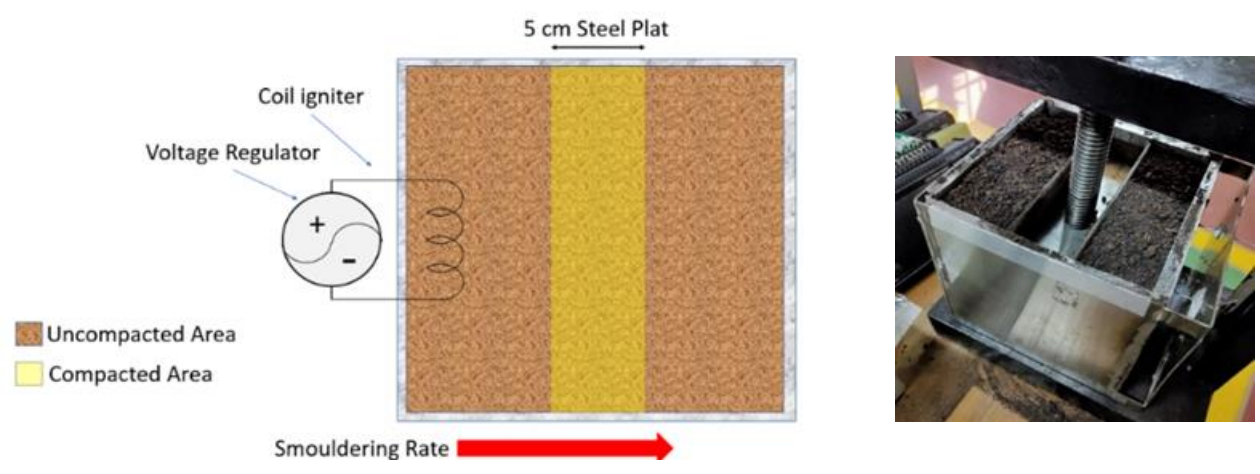

Fig. 2. Peat Compaction Area

\section{Results}

Figure 3 and 4 display images of the smoldering peat taken by a FLIR infrared camera (FLIR) and a visual camera on the same timeline. The temperature on the infrared camera ranges from $50^{\circ} \mathrm{C}$ to $550^{\circ} \mathrm{C}$ by considering the maximum temperature of smoldering peat. As shown in the legend, the brighter the color on the temperature scale, the higher the temperature recorded.

In the first hour (Figure 3(a)), the heat generated from the coil heater has started the ignition process in the peat bed close to the electric heater. The smoldering front propagates to the right side of the reactor. It propagates vertically and horizontally to the area where there is an oxygen supply and fuel-rich zone. After 4 hours of the smoldering process (Figure 3(b)), the temperature has declined, and the smoldering is obstructed in the central area. The obstruction phenomena arise because the compacted peat succeeds in reducing the permeability and the peat pores. As a result, the soil oxygen is decreasing and sufficient to make the smoldering is blocked.

Nevertheless, after 7 hours (Figure 3(c)), the fire began to propagate through the central area due to the rising temperature around the compacted peat. The heat accumulates from the surface to the bottom of the peat could achieve conditions for smoldering combustion to propagate. After 23 hours (Figure $3 \mathrm{~d}$ ), the smoldering front has spread to all parts of the reactor, showing the increasing temperature at every point. It also shows the formation of ash and soil shrinkage due to reduced moisture content and combustion. 

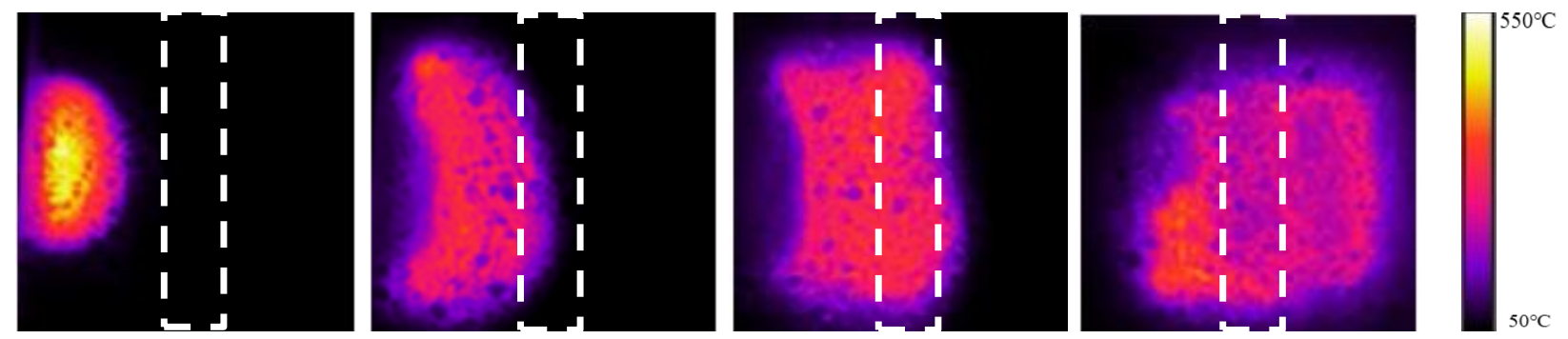

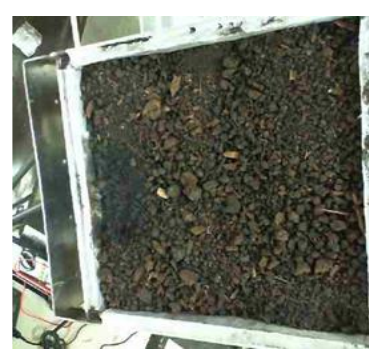

(a)

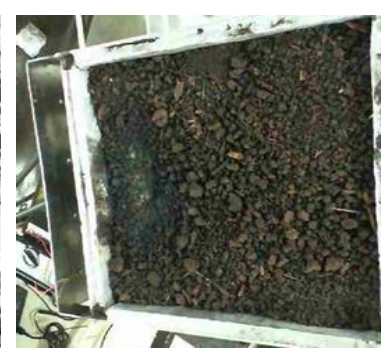

(b)

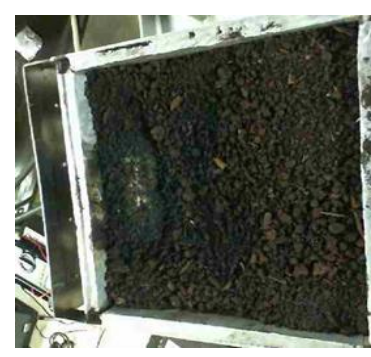

(c)

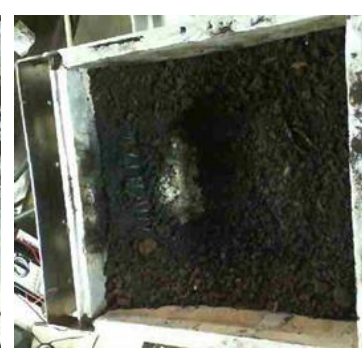

(d)

Fig. 3. Sequences of images taken by a FLIR infrared camera (above) and a visual camera (below) at (a) 1 hour, (b) 4 hours, (c) 7 hours, (d) 23 hours after initial ignition. The white dotted lines show the compacted areas of the peat bed

Later, after 51 hours (Figure 4(a)), a decrease in temperature was observed on the surface of the peat. Nevertheless, there is a sharp temperature rise at one point in the reactor. That point is a hole that was previously used to check the temperature with a thermocouple. About an hour later (Figure 4(b)), smoldering combustion is reappeared. The re-ignition process happens due to the piercing of the thermocouple makes the oxygen re-supplied, so the temperature rises sharply. Previously, the ash formed by combustion began to cover the shrinking peat, making it difficult to gain oxygen supply from the environment. The smoldering continues to spread, as shown in Figures 4(c) and (d).
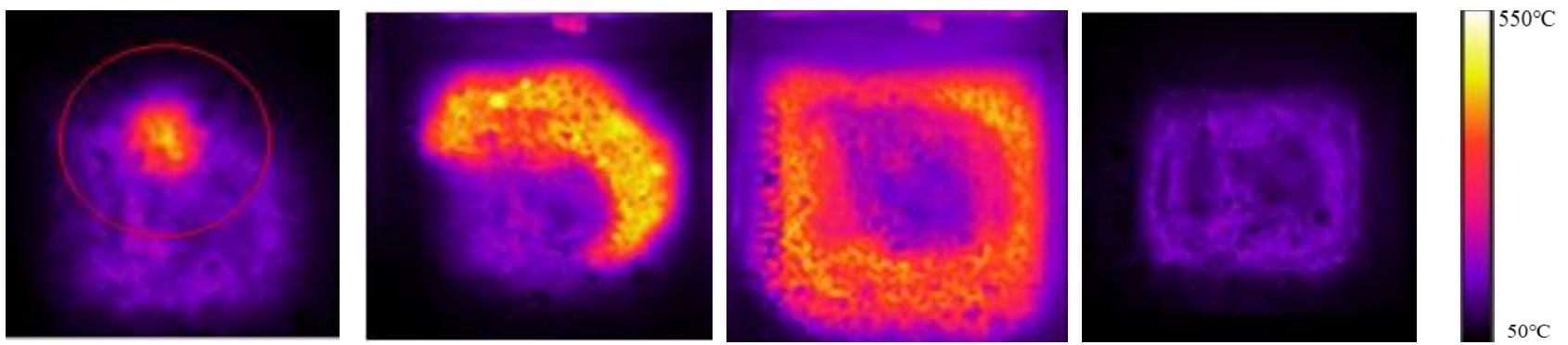

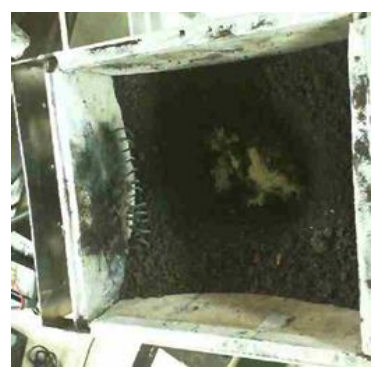

(a)

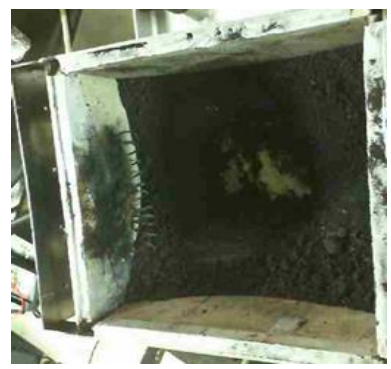

(b)

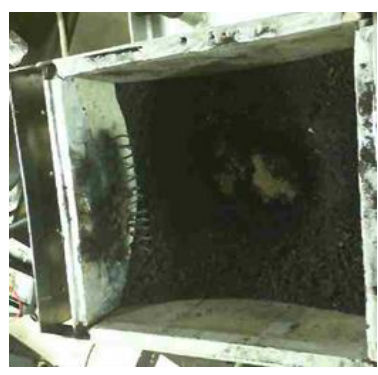

(c)

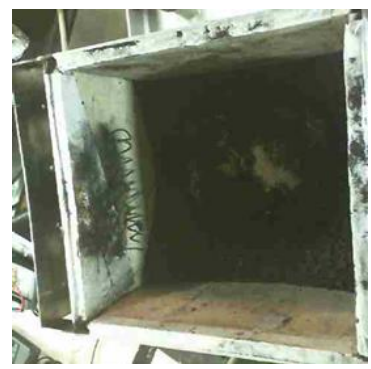

(d)

Fig. 4. Sequences of images taken by a FLIR infrared camera (above) and a visual camera (below) at (a) 51 hours, (b) 52 hours, (c) 54 hours, (d) 70 hours after initial ignition 
As illustrated in Figure 5, the reappearance of the smoldering front was facilitated by the ignition of peat char that collapses and gathers with pre-heated peat on the bottom of the peat layers. Char is a result of incomplete combustion, which could re-ignite the combustion process when contacted with pre-heated peat.

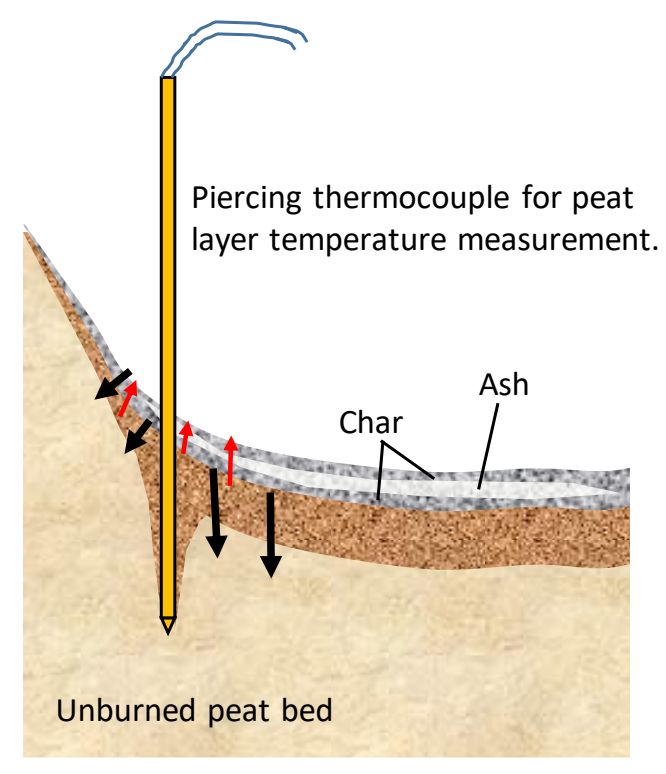

(a)

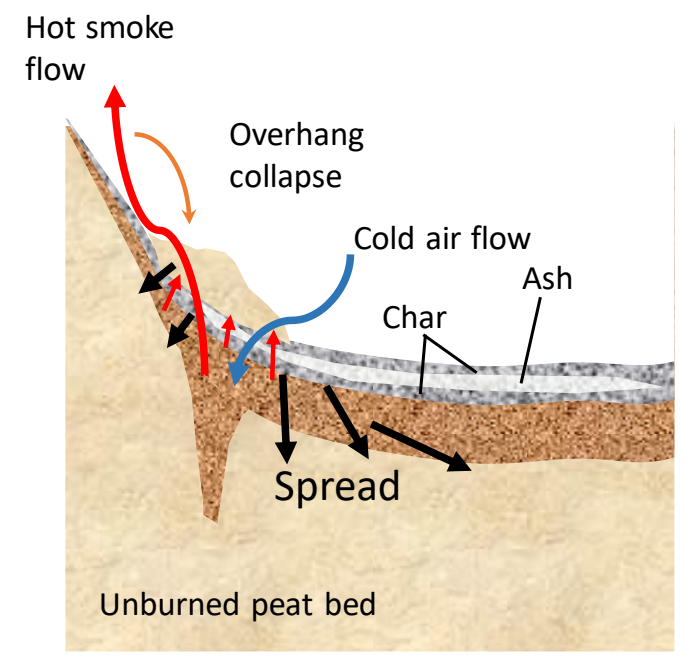

(b)

Fig. 5. Effect of piercing thermocouple on the re-ignition process due to the intrusion of fresh airflow and collapse of peat layer, (a) when the thermocouple was inserted, and (b) change in gas and heat exchange after thermocouple was removed, adapted from [16]

After 70 hours, the smoldering process ceased. The end of the smoldering process was confirmed by the surface temperature below $100^{\circ} \mathrm{C}$, no unburnt soil, a lot of formed ash, and a constant decrease in soil temperatures. After long observation, there was no increase in temperature, and the temperature reduction phenomenon remains unchanged; thus, the smoldering combustion is stopped completely.

\section{Conclusions}

From this study, it can be concluded that decreasing soil permeability using the compaction method can obstruct the rate of smoldering on peat. However, this method cannot directly prevent peat fires because compacting occurs on the peat surface, and smoldering will still propagate. The experiments are also less than optimal because of the short time duration of the compaction pressure, so the soil has not reached $100 \%$ plastic condition. Calculating the pressure during compaction and increasing the duration when maintaining the compaction pressure could maximize its effects. The smoldering rate slows down temporarily due to the lack of oxygen supply when ashes cover the surface. However, peat char gathers with pre-heating peat may raise the temperature and continue the smoldering process due to peat collapse phenomena.

\section{Acknowledgment}

The authors would like to thank the financial support provided by the Ministry of Education, Culture, Research and Technologyof the Republic of Indonesia through Penelitian Terapan Unggulan Perguruan Tinggi (PTUPT) 2019-2020 funding scheme with a contract number : Surat Keputusan 


\section{Nomor 8/AMD/E1/KP.PTNBH/2020 and 332/PKS/R/01/2020 and NKB- 2961/UN2.RST/HKP.05.00/2020 managed by the Directorate for Research and Public Services (DRPM) Universitas Indonesia.}

\section{References}

[1] Dhowian, A. W., and T. B. Edil. "Consolidation behavior of peats." Geotechnical Testing Journal 3, no. 3 (1980): 105114. https://doi.org/10.1520/GTJ10881J

[2] Anggraini, Vivi. "Shear strength improvement of peat soil due to consolidation." PhD diss., Universiti Teknologi Malaysia, 2006.

[3] "Luas dan sebaran lahan gambut di Indonesia." [Online]. Available: https://pantaugambut.id/pelajari/apa-itugambut/luas-dan-sebaran-lahan-gambut-di-indonesia.

[4] Ratnasari, Nadhira Gilang. "Pengendalian kebakaran membara gambut berbasis busa foam= Laboratory scale experimental study of foam suppression on smoldering combustion of a tropical peat." (2018).

[5] P. Gambut. "Laporan Pantau Gambut Temuan dan Analisis Implementasi Restorasi." 2018.

[6] Mongabay. "Bencana Asap di Sumatera dan Kalimantan, Mengapa Lahan Gambut Terus Terbakar?" (2019). [Online]. Available: https://www.mongabay.co.id/2019/09/15/.

[7] Glauber, A. J., and I. Gunawan. "The cost of fire: An economic analysis of Indonesia's 2015 fire crisis." The World Bank http://pubdocs. worldbank. org/en/643781465442350600/Indonesia-forest-fire-notes. pdf (2016).

[8] Rein, Guillermo. "Smouldering combustion phenomena in science and technology." International Review of Chemical Engineering 1 (2009): 3-18.

[9] Ohlemiller, T. J. "Smoldering combustion." SFPE handbook of fire protection engineering 3 (2002).

[10] Palamba, Pither, Mohamad Lutfi Ramadhan, Agus Sunjarianto Pamitran, Gatot Prayogo, Engkos Achmad Kosasih, and Yulianto Sulistyo Nugroho. "Drying kinetics of Indonesian peat." Mechanical Engineering 9, no. 5 (2018): 10061014. https://doi.org/10.14716/ijtech.v9i5.805.

[11] Hadden, R., and G. Rein. "Burning and water suppression of smoldering coal fires in small-scale laboratory experiments." Coal and peat fires: a global perspective 1 (2011): 317-326. https://doi.org/10.1016/B978-0-444$\underline{52858-2.00018-9}$

[12] I. Soemardikatomodjo. "Motor Grader dan Compactor." in Alat-Alat Berat (2003).

[13] Peurifoy, Robert L., Clifford J. Schexnayder, Robert L. Schmitt, and Aviad Shapira. Construction planning, equipment, and methods. McGraw-Hill Education, 2018.

[14] Hu, Yuqi, Wuquan Cui, and Guillermo Rein. "Haze emissions from smouldering peat: The roles of inorganic content and bulk density." Fire Safety Journal 113 (2020): 102940.

[15] Andriesse, J. P. "Nature and management of tropical peat soils." Food \& Agriculture Org. 59, 1988.

[16] Huang, Xinyan, Francesco Restuccia, Michela Gramola, and Guillermo Rein. "Experimental study of the formation and collapse of an overhang in the lateral spread of smouldering peat fires." Combustion and Flame 168 (2016): 393-402. https://doi.org/10.1016/j.combustflame.2016.01.017 